\title{
Andrographolide Exerts Pro-Osteogenic Effect by Activation of Wnt/ $\beta$-Catenin Signaling Pathway in Vitro
}

\author{
Tongmeng Jiang ${ }^{a, b}$ Bo Zhou Li Huang $^{a, b}$ Huayu $\mathrm{Wu}^{\mathrm{c}}$ Jiancheng Huanga,b \\ Tihong Liang ${ }^{a, b}$ Hui Liu ${ }^{a}$ Li Zheng, Jinmin Zhao a,b,d,e
}

a'Guangxi Key Laboratory of Regenerative Medicine, Guangxi Medical University, Nanning, ${ }^{\text {bDepartment }}$ of Orthopaedics Trauma and Hand Surgery, The First Affiliated Hospital of Guangxi Medical University, Nanning, 'Department of Cell Biology \& Genetics, School of Premedical Sciences, Guangxi Medical University, Nanning, dKey Laboratory of Regenerative Medicine of Guangxi High School, Guangxi Medical University, Nanning, eThe Medical and Scientific Research Center, Guangxi Medical University, Nanning, China

\section{Key Words}

Andrographolide • Osteogenic $・$ WNT • $\beta$-catenin • Osteoblast

\begin{abstract}
Background/Aims: Osteoporosis is a metabolic bone disorders that tortures about millions of people worldwide. Recent studies showed that Andrographolide (AP) is a promising natural compound for the treatment of osteoclast-related bone diseases. However, its potential in treatment of osteoporosis has not been fully explored. Methods: In this study, the effect of AP on osteoblasts metabolism was investigated via the detection of cell proliferation, cell viability, ALP activity, the expression of osteogenic specific genes including runt-related transcription factor 2 (RUNX2), bone sialoprotein (BSP), osteocalcin (OCN), Bone morphogenic protein-2 (BMP2) and Alkaline phosphatase(ALP) for 3, 5 and 7 days respectively. Further exploration of the association of AP with WNT/ $\beta$-catenin signaling pathway was performed by examination of the expression of WNT related genes and proteins. Results: Results showed that AP of 4.46 and $8.92 \mu \mathrm{M}$, especially $8.92 \mu \mathrm{M}$ was beneficial to osteogenic differentiation by upregulating ALP activity and expression of osteogenic related genes $(P<0.05)$. Pathway analyses identify canonical WNT/ $\beta$-catenin pathway as an important mediator in AP-induced osteogenesis. Conclusion: This study indicates that AP exerts its pro-osteogenic potential via activation of the WNT/ $\beta$-catenin in osteoblasts and thus may represent a candidate of therapeutic agent for osteoporosis.
\end{abstract}

T. Jiang and B. Zhou contributed equally to this work.

\section{Li Zheng}

and JinMin Zhao
Shuangyong Road \#22, Nanning, Guangxi (China)

Tel.+86-07715358132, Fax+86-07715350975, E-Mail zhengli224@163.com

Tel. +86-07715350189, Fax +86-07715350189, E-Mail zhaojinmin@126.com 


\section{Cellular Physiology Cell Physiol Biochem 2015;36:2327-2339 \\ \begin{tabular}{l|l} 
DOI: 10.1159/000430196 & $\begin{array}{l}\text { C } 2015 \text { S. Karger AG, Basel } \\
\text { www.karger.com/cpb }\end{array}$ \\
\hline
\end{tabular}}

\section{Introduction}

Osteoporosis is a metabolic bone disorders that tortures about 200 million people worldwide, mostly women (approximately 80\%) and eldermen [1].Drug therapy is among the most typical choices for treatment of patients with osteoporosis. The amino-bisphosphonates are first-line therapy with proven efficacy to reduce fracture risk at the spine, hip, and other nonvertebral skeletal sites. However, some unexpected possible adverse effects have been reported following the use of bisphosphonates in millions of patients in clinical practice, such as osteonecrosis of the jaw, atypical femur fractures, atrial fibrillation, and esophageal cancer [2].

Recently, plant and plant-derived natural products that exhibit minimum side effects and are available in cost effective manner have received considerable attention [3]. Andrographispaniculata(A. paniculata), a traditional Chinese herbal medicine, is widely used for the treatment of fever, inflammation, diarrhoea and other infectious diseases in clinic without any apparent side effects [4,5]. Andrographolide (AP) is one of the main active constituents of A. paniculata [6,7], which was reported to have anti-inflammatory and anticancer activities [8-13]. Recent studies showed that AP is a promising natural compound for the treatment of osteoclast-related bone diseases [14, 15]. Rami Al Batran and et al. reported that AP suppresses alveolar bone resorption caused by Porphyromonasgingivalis in rats [16]. As we have known, metabolic homeostasis of bone is achieved through adelicate balance between osteoblastic bone formation and osteoclastic bone resorption. Although AP plays important role in osteoclast related bone resorption, its potential in treatment of osteoporosis has not been fully explored. The association of AP with bone formation and related mechanism are still unknown to us.

By regulating the activation of different bone cells in bone remodeling process, multiple pathways are exploited in the development of new therapies for osteoporosis. The canonical $\mathrm{Wnt} / \beta$-catenin pathway is not only one of the most important signaling pathways governing bone homeostasis but also be involved in the progression of osteoporosis [17-21]. The activation of Wnt/ $\beta$-catenin pathway, which is a common signaling pathway regulating the cell differentiation prevents skeletal aging and inflammation [22]. Effect of ethanol promoting osteogenesis was displayed through Wnt/ $\beta$-catenin pathways in the shift of BMSCs towards osteoblast lineage [23]. In the study of Tapia-Rojas C an et al., AP activates the canonical Wnt signalling pathway in the nervous system by inducing the transcription of Wnt target genes by a mechanism that by-passes Wnt ligand binding to its receptor [24]. This implied that AP may exert effects on bone formation though the activation of Wnt signaling pathway.

Given the importance of the Wnt/ $\beta$-catenin pathway in osteoporosis and the effect of AP on Wnt signaling pathway, as well as the association of AP with osteoclast, we hypothesized that AP may be potential inhibitor of osteoporosis. In this study, the effects of AP on osteoblast and activation of Wnt/ $\beta$-catenin signaling pathway were investigated. This study may provide reference for its application in treatment of osteoporosis.

\section{Materials and Methods}

Preparation and treatment of AP

AP was obtained from Chengdu Must Bio-technology Co. LTD. (Sichuan, China). Prior to the experiment, stock solution was prepared by dissolving AP in dimethyl sulphoxide (DMSO) with the final concentration of $100 \mu \mathrm{M}$.The stock solution was diluted with culture medium immediately before treatment.The final concentration of DMSO was less than $0.1 \%$ in all experiments.

Isolation and culture of osteoblasts

Osteoblasts were isolated from neonatal (3-7days old) SD rat pups calvaria using sequential digestion [25]. After removal of sutures and adherent mesenchymal tissues, calvaria were subjected to five sequential (10-15 min) digestions in the media containing $1 \mathrm{mg} / \mathrm{ml}$ collagenase type I (Gibco, USA)at $37^{\circ} \mathrm{C}$ in shaking 


\section{Cellular Physiology Cell Physiol Biochem 2015;36:2327-2339 \begin{tabular}{ll|l} 
and Biochemistry & $\begin{array}{l}\text { DOI: 10.1159/000430196 } \\
\text { Published online: July 27, 2015 }\end{array}$ & $\begin{array}{l}\text { ○ 2015 S. Karger AG, Basel } \\
\text { www.karger.com/cpb }\end{array}$ \\
\hline
\end{tabular} \\ Jiang et al.: Andrographolide Exerts Pro-Osteogenic Effect}

water bath at 120rpm.Supernatants were pooled from the second to fifth digestions in a tube. Cells were re-suspended in alpha-modified Eagle's medium ( $\alpha$-MEM, Gibco, USA) containing $10 \%(v / v)$ fetal bovine serum (FBS, Gibco, USA) with 1\% penicillin/streptomycin solution (penicillin $100 \mathrm{U} / \mathrm{mL}$, streptomycin 100 $\mathrm{U} / \mathrm{mL}$ ) and then transferred in T-25 $\mathrm{cm}^{2}$ culture flasks. The flasks were maintained in 5\% $\mathrm{CO} 2$ incubator (Thermo Scientific ${ }^{\mathrm{TM}}$ Forma Series II Water-Jacketed, USA) at $37^{\circ} \mathrm{C}$ with the culture medium changed every 3 days. Cells of passage 3 at $80-90 \%$ confluence were used for further studies.

\section{Cytotoxicity assay}

Osteoblasts were cultured in $\alpha$-MEM containing $10 \%$ FBS and $1 \%(\mathrm{v} / \mathrm{v})$ antibiotics and seeded into a 96-well plates at a density of $1 \times 10^{3}$ cells/well for $24 \mathrm{~h}$. The medium was replaced with a medium containing AP prepared with different concentrations $(0-100 \mu \mathrm{M})$ in triplicate for 3 days. After exposure period, 10ul of $5 \mathrm{mg} / \mathrm{ml}$-(4,5)-dimethylthiahiazo(-z-y1)-3,5-diphenytetrazoliumromide (MTT, Gibco, USA) solution was added to each wells and further incubated at $37^{\circ} \mathrm{C}$. After 4 hours, culture medium was removed and dimethyl sulfoxide (DMSO, Gibco, USA) was added with $100 \mu \mathrm{l}$ per well for crystal solubilization. The plates were placed in the dark at $37^{\circ} \mathrm{C}$, with continuous gentle shaking for $10 \mathrm{~min}$ to thoroughly dissolve the crystal. The spectrometric absorbance at $570 \mathrm{~nm}$ was read using a microplate reader (Thermo Fisher Scientific, UK). As determined by MTT analysis, Results of showed that AP of $8.92 \mu \mathrm{M}$ could best promote cell growth. Therefore, concentrations of 4.46, 8.92 and $17.84 \mu \mathrm{M}$ were chosen for further investigations.

\section{Cell proliferation analysis}

Cells were treated with AP at four concentrations $(0 \mu \mathrm{M}$ as control, $4.46 \mu \mathrm{M}, 8.92 \mu \mathrm{M}$, and $17.84 \mu \mathrm{M})$ for 3, 5 and 7days. Proliferation of osteoblasts cultured with various concentrations of AP was detected by the MTT assay. Breifly, $100 \mu \mathrm{L}$ MTT was added in each well at $37^{\circ} \mathrm{C}$ for $4 \mathrm{~h}$, and then the supernatant was discarded and dissolved in $1 \mathrm{~mL}$ DMSO. Before test, all samples were transferred to 96-well plates, with a concentration of $200 \mu \mathrm{L} /$ well. The absorbance was measured at $570 \mu$ Mand recorded under a microplate reader (Bio-Rad 550, USA).

\section{Alkaline phosphatase (ALP) activity}

Alkaline phosphatase (ALP) activity assay was carried out by using ALP detection reagent kit (Nanjing Jiancheng Bioengineering Research Institute, China) following the manufacturer's instructions. After centrifuged at $2500 \mathrm{rpm}$ for $10 \mathrm{~min}$, the supernatant of the medium was harvested for subsequent assay. After adding buffer solution, matrix solution, water bathing and developing, the optical density (OD) value was detected at $520 \mu \mathrm{M}$ with a microplate reader (Thermo Fisher Scientific, UK). Subsequently, the activity value was calculated with computational formula. Each sample was analyzed in triplicate to reduce randomization error.

\section{Cell viability assay}

Vital staining was performed with $5 \mu \mathrm{M}$ phosphate buffered fluorescein diacetate (FDA) (Life Technologies (AB \& Invitrogen) USA)/ and $20 \mu \mathrm{M}$ propidium iodide (PI, Life Technologies (AB \& Invitrogen), USA)) in phosphate buffered saline (PBS) incubated in the dark for $5 \mathrm{~min}$ at $37^{\circ} \mathrm{C}$. Analysis was performed with a laser scanning confocal microscope (Nikon A1, Japan).

\section{Cell morphology}

After cultured for 3, 5 and 7 days respectively, cells were fixed with 4\% paraformaldehyde for 30 min and successively stained by hematoxylin-eosin (HE) using HE kit (Jiancheng Biotech, China). Finally, cells were observed and photographed utilizing an Upright microscope (Leica DM1000, Germany).

\section{Immunohistochemical staining}

For immunohistochemical staining, cells were subsequently fixed with $4 \%$ paraformaldehyde and endogenous peroxidase was quenched with3\% H2O2 in methanol. Prior to staining, non-specific binding was blocked by goat serum for $10 \mathrm{~min}$ at room temperature. They were then incubated with primary antibody (osteocalcin, OCN, Bioss, China) at $37^{\circ} \mathrm{C}$ for $3 \mathrm{~h}$. The horseradish peroxidase-conjugated goatantirabbit IgGAb (Sigma) was applied at $37^{\circ} \mathrm{C}$ for $1 \mathrm{~h}$. The chromogenic reaction of OCN was visualized by 3,3-diaminobenzidine tetrahydrochloride (DAB) kit (Boster, China) and counterstained with haematoxylin. The cells were observed and photographed utilizing an Upright microscope (Leica DM1000, Germany). 


\section{Cellular Physiology Cell Physiol Biochem 2015;36:2327-2339 \begin{tabular}{ll|l} 
and Biochemistry & $\begin{array}{l}\text { DOI: 10.1159/000430196 } \\
\text { Published online: July 27, } 2015\end{array}$ & $\begin{array}{l}\text { ○ 2015 S. Karger AG, Basel } \\
\text { www.karger.com/cpb }\end{array}$ \\
\hline
\end{tabular}}

Jiang et al.: Andrographolide Exerts Pro-Osteogenic Effect

Table 1. Primers for polymerase chain reaction (GAPDH glyceraldehyde-3-phosphate dehydrogenase, ALP alkaline phosphatase, BSP bone sialoprotein, OCN osteocalcin, BMP-2 bone morphogenetic protein-2, Runx2 runt-related transcription factor 2, $\beta$-catenin, Wnt4, Wnt5a, Fzd2 Frizzled2, Gsk-3b)

\begin{tabular}{lll}
\hline Gene name & Forward primer & Reverse primer \\
\hline GAPDH & 5'-GGCTCTCTGCTCCTCCCTGT-3' & 5'-CTGTGCCGTTGAACTTGCCG-3' \\
ALP & 5'-GTTACAAGGTGGTGGACGGT-3' & 5'-ACAGTGGTCAAGGTTGGCTC-3' \\
BSP & 5'-CCGGGAGAACAATCCGTGCC-3' & 5'-AAAGCACTCGCCATCCCCAA-3' \\
OCN & 5'-CAGGTGCAAAGCCCAGCGAC-3' & 5'-TGGGGCTCCAAGTCCATTGTT-3' \\
BMP-2 & 5'-TGCTCAGCTTCCATCACGAA-3' & 5'-AATTTTGAGCTGGCTGTGGC-3' \\
RUNX2 & 5'-CCAAGTGGCCAGGTTCAACG-3' & 5'-GGGATGAGGAATGCGCCCTA-3' \\
B-catenin & 5'-ACTCCAGGAATGAAGGCGTG-3' & 5'-CCAGTCCGAGATCAGCAGTC-3' \\
Wnt4 & 5'-TCTCCGAAGAGGAAACGTGC-3' & 5'-CAGGGAGTCCAGTGTGGAAC-3' \\
Wnt5a & 5'-CGAGAAAGGGAACGAATC-3' & 5'-CACTTGACATAGCAGCACCA-3' \\
Fzd2 & 5'-ACGGCTCCATGTTCTTCTCG-3' & 5'-ATGGTGTAGCAACCGGACAG-3' \\
Gsk-3b & 5'-CTGGCCACCATCCTTATCCC-3' & 5'-TAAGTGCTGGTCTTCCCTGC-3' \\
\hline
\end{tabular}

Western blot analysis

Cells were washed with cold phosphate-buffered saline (vehicle), and whole-cell lysates were prepared by the addition of lysis buffer Sigma-Aldrich containing a protease inhibitor mixture Sigma-Aldrich. Cytoplasmic and nuclear fractions were prepared using the nuclear and cytoplasmic extraction kit(KeyGEN BioTECH, China) according to the manufacturer's protocol. 30-50 ug of protein was loaded per lane and separated on a $10 \%$ polyacrylamide gel, followed by transfer to a PVDF membrane (Millipore, Billerica, MA, USA) by electroblotting. Membrane was blocked for nonspecific binding in 5\% nonfat dry milk and followed by incubation with a primary antibody (Abcam) at $4^{\circ} \mathrm{C}$ overnight. The membranes were washed and probed with an Alexainfrared dye-conjugated secondary antibodies (Invitrogen) and visualized by the Odyssey Infrared Imaging System (LI-COR) according to the manufacturer's instructions.

\section{Gene expression analysis}

RNA was extracted from cell layers at days 3, 5 and 7 using an RNeasy RNA extraction kit (Tiangen Biotechnology; Beijing, China) according to the manufacturer's instructions, and quantified spectrometrically. Starting from 1 ug RNA, 20 uL of cDNA were synthesised using reverse transcription kit (Fermentas company, USA)and and then cDNAs were amplified using SYBR-Green mix kit (Roche company, Germany).Quantitative RT-PCR reactions were performed and monitored using the Mastercycler®eprealplex DetectionSystem (Eppendorf, Hamburg, Germany) and RealMasterMixCyberGreen (Eppendorf). Genes of interest were analysed in cDNA samples (5 uL, $50 \mathrm{uL} /$ reaction) using the 2- $\Delta \Delta \mathrm{CT}$ method relative to GAPDH. Each sample was repeated three times for each gene. The primers used for PCR were designed as follows Table 1.

\section{Statistical analysis}

The data were analyzed using the SPSS16.0 statistical package(Chicago, USA). The data are presented as the mean \pm SEM. One-way ANOVA and Student'sunpaired t-test were used for statistical analysis. For all tests, $\mathrm{P}<0.05$ was considered to be statistically significant.

\section{Results}

Cytotoxicity assay

As shown in Fig. 1 (A), compared with the control group $(0 \mu \mathrm{M}), 4.46-5.0 \mu \mathrm{M}$ AP indicated low or no cytotoxicity. 4.46-8.92 $\mu \mathrm{M}$ AP significantly accelerated cell growth with the more obvious effect at the dose of $8.92 \mu \mathrm{M}(\mathrm{P}<0.05)$. In contrast, the concentration ranging from 17.84 to $30 \mu \mathrm{M}$ of AP showed inhibition of proliferation of rat osteoblasts in vitro, compared 


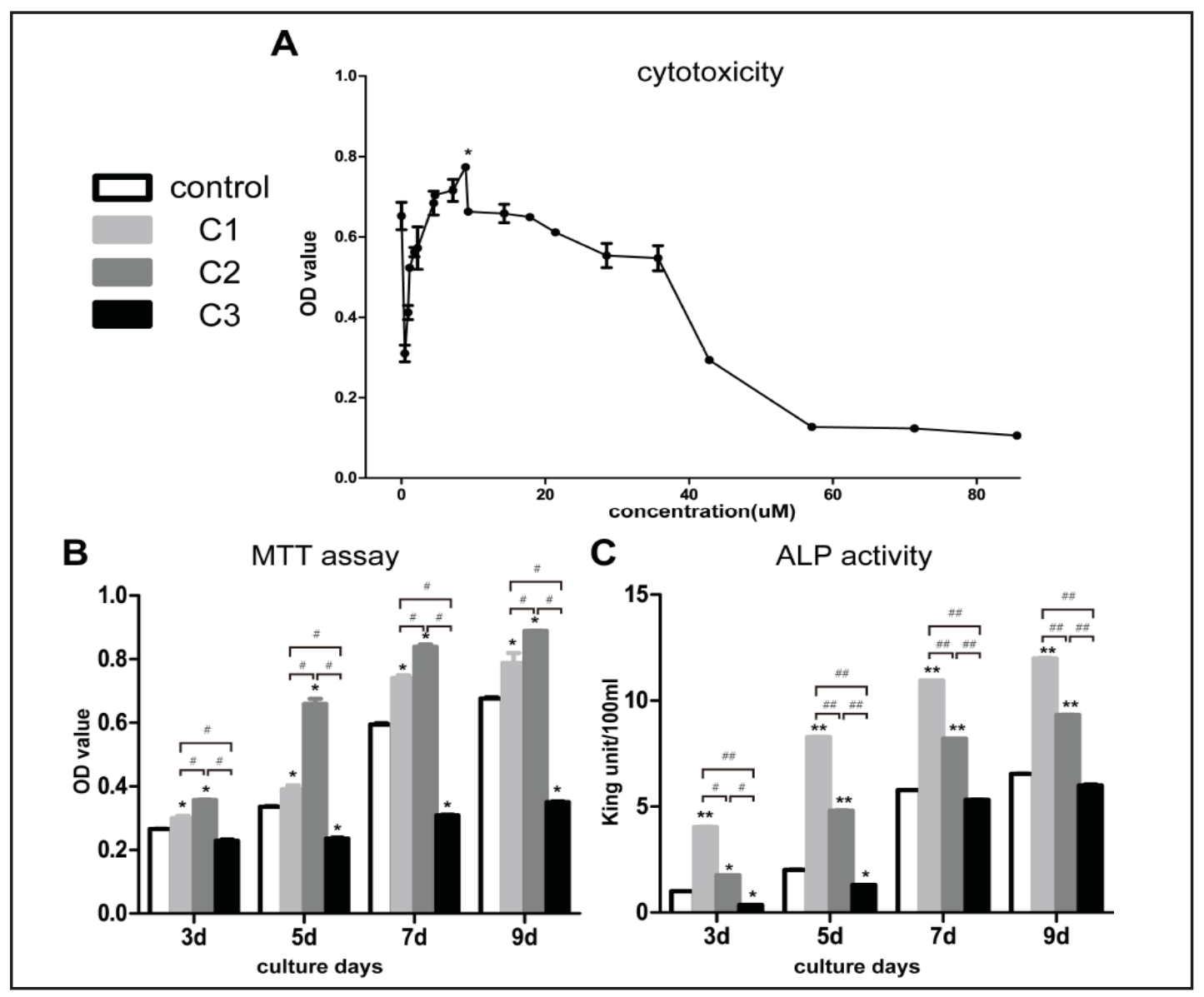

Fig. 1. (A) Cytotoxicity assay was determined by (3-(4,5-dimethylthiazol-2-yl)-2,5-diphenyltetrazolium bromide) MTT of rat osteoblast at various concentrations $(0 \mu \mathrm{M}$ as control, $4.46 \mu \mathrm{M}$ as $\mathrm{C} 1,8.92 \mu \mathrm{M}$ as $\mathrm{C} 2$, and $17.84 \mu \mathrm{M}$ as C3) of Andrographolide (AP). (B) MTT was used to analyze cell proliferation of rat osteoblast at various concentrations $(0 \mu \mathrm{M}$ as control, $4.46 \mu \mathrm{M}$ as $\mathrm{C} 1,8.92 \mu \mathrm{M}$ as $\mathrm{C} 2$, and $17.84 \mu \mathrm{M}$ as $\mathrm{C} 3)$ of Andrographolide (AP). * \# indicate $\mathrm{P}<0.05, * *$,\#\# indicate $\mathrm{P}<0.01$ and ${ }^{* * *}$, \#\#\# indicate $\left.\mathrm{P}<0.001\right)(\mathrm{C})$ Time-course of alkaline phosphatase (ALP) activity, osteogenic specific genes and OCN staining of osteoblasts at various concentrations $(0 \mu \mathrm{M}, 4.46 \mu \mathrm{M}, 8.92 \mu \mathrm{M}$, and $17.84 \mu \mathrm{M})$ of AP. Aa Relative ALP activity (units/mg protein) expressed as mean \pm SEM. ${ }^{*}$,\# indicate $\mathrm{P}<0.05,{ }^{* *}$,\#\# indicate $\mathrm{P}<0.01$ and ${ }^{* * *}$, \#\#\# indicate $\mathrm{P}<0.001$ ).

to that of control group. Based on the preliminary screening of drugs, concentrations of 0 , 4.46, 8.92 and $17.84 \mu \mathrm{M}$ were chosen for further study.

\section{Cell proliferation}

Fig. 1 (B) shows that the proliferation of osteoblasts is both time- and dose-dependent. Osteoblasts cultured with 4.46 and $8.92 \mu \mathrm{M}$ of AP grew faster than both control and $17.84 \mu \mathrm{M}$ group $(\mathrm{P}<0.05)$ in the same culture period. Among the three AP groups, $8.92 \mu \mathrm{M}$ of AP was the optimal concentration which stimulated the proliferation of cells the most prominently.

\section{Alkaline phosphatase (ALP) activity}

As shown in Fig. 1 (C), osteoblasts treated with both 4.46 and $8.92 \mu \mathrm{M}$ of AP exhibited higher ALP activity than those in the control at day 3, 5 7and 9. By contrast, the dose of $17.84 \mu \mathrm{M}$ showed lower ALP than the control group. On the whole, the trend of ALP activity increased from day 3 to 9 . The results of ALP activity demonstrated that AP was beneficial to osteogenic differentiation, especially at the concentration of $4.46 \mu \mathrm{M}(\mathrm{P}<0.01)$. 


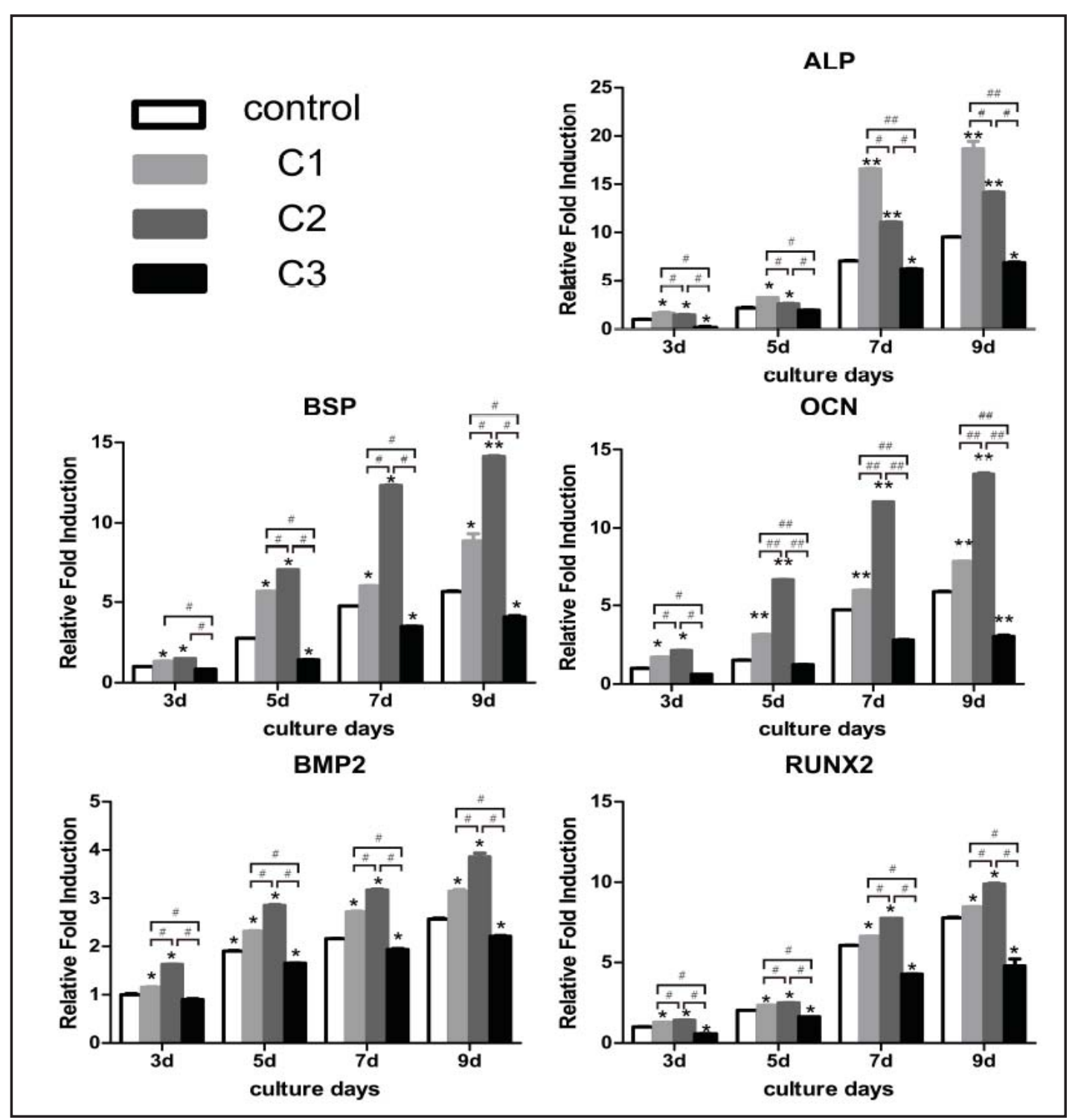

Fig. 2. Quantitative real-time PCR was used to analyze the progression of the expression of osteogenic genes OCN , BMP-2, ALP, BSP, RUNX2 in osteoblasts cultured in various concentrations of AP for 3, 5, 79 days. The control group value was set to 1 and values are expressed as means \pm SEM. ${ }^{*}$,\# indicate $\mathrm{P}<0.05,{ }^{* *}$, \#\# indicate $\mathrm{P}<0.01$ and ${ }^{* * *}$, \#\#\# indicate $\mathrm{P}<0.001$ ) (BMP-2 bone morphogenetic protein-2, Runx2 runt-related transcription factor 2, ALP alkaline phosphatase, BSP bone sialoprotein, OCN osteocalcin).

\section{Cell viability assay}

Cell viability was determined by FDA/PI staining (Fig. 3), in which viable cells were stained green and dead cells were stained red. The results revealed that 4.46 and $8.92 \mu \mathrm{M}$ of AP exert positive effect on osteoblast survival, which was in accordance with the result of cell proliferation by MTT analysis. $17.84 \mu \mathrm{M}$ of AP presents an inferior position in osteoblast survival .Among the experimental groups, concentration of $8.92 \mu \mathrm{M}$ was superior to others.

\section{Cell morphology}

Evaluation of osteoblasts morphology by HE staining showed that osteoblasts treated by 4.46 and $8.92 \mu \mathrm{M}$ of AP grew better than control and $17.84 \mu \mathrm{M}$ of AP at the same time point of treatment (Fig. 4). In the AP groups, the most cells were present after treated with 8.92 $\mu \mathrm{M}$ of AP.

\section{KARGER}




\section{Cellular Physiology Cell Physiol Biochem 2015;36:2327-2339 \begin{tabular}{l|l|l} 
DOI: 10.1159/000430196 & (C) 2015 S. Karger AG, Basel
\end{tabular} \begin{tabular}{l|l} 
and Biochemistry Published online: July 27, 2015 & www.karger.com/cpb \\
\hline
\end{tabular}}

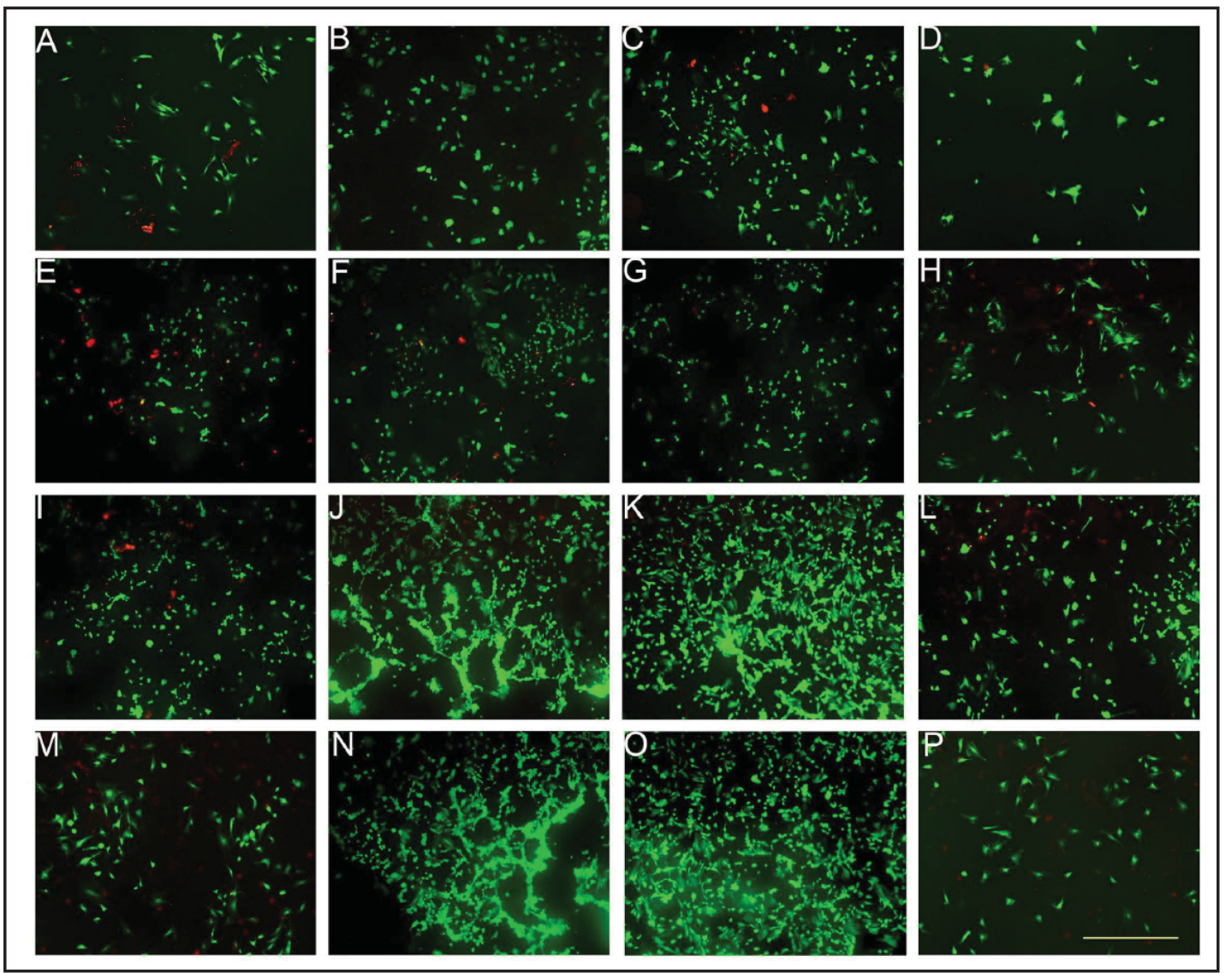

Fig. 3. Cell viability was determined by FDA/PI staining of osteoblasts at various concentrations $(0 \mu \mathrm{M}$, $4.46 \mu \mathrm{M}, 8.92 \mu \mathrm{M}$, and $17.84 \mu \mathrm{M}$ ) of AP.(A-D ,E-H, I-L, M-P) Staining of osteoblasts at various concentrations$(0 \mu \mathrm{M}, 4.46 \mu \mathrm{M}, 8.92 \mu \mathrm{M}$, and $17.84 \mu \mathrm{M})$ of AP on day 3,5,7,9, respectively. The scale bar is $1000 \mu \mathrm{m}$.

\section{Immunohistochemical staining}

We evaluated the deposition ofmatrixin ratosteoblastsinvitrowithimmunohistochemical staining of OCN (Fig. 5 (A-P)).The negative control staining was presented in Fig. 5 (Q). There were more OCN positive staining (as shown in dark-brown) in 4.46, $8.92 \mu \mathrm{M}$ AP groups than the control group, and the positive rate was showed in Fig. 5 (R). In addition, AP at dose of $17.84 \mu \mathrm{M}$ was inferior to others in terms of OCN staing. It is suggested that AP at dose of 4.46 $\mu \mathrm{M}$ and $8.92 \mu \mathrm{M}$ exerted pro-osteogenic effect on mature osteoblasts.

\section{Gene expression analysis}

The expression of ALP, OCN, BSP, BMP2, Runx2, $\beta$-catenin, Wnt4, GSK3b, WNT5a and Fzd2 was detected at day3,5,7,9 (Fig. 2, Fig. 6 (A)).When compared to GAPDH mRNA level, the relative levels of the ALP, OCN, BSP, BMP2, Runx2, $\beta$-catenin, Wnt4 mRNA were all significantly up-regulated by $4.46,8.92 \mu \mathrm{M}$ AP than the control group.On the contrary, gene expression was cutting down by $17.84 \mu \mathrm{M}$ AP. Among all the groups, AP at the concentration of $8.92 \mu \mathrm{M}$ exhibited the best performance with regard to the up-regulation of expression of OCN, BSP, BMP2, Runx2, $\beta$-catenin, Wnt4 genes. In line with the ALP activity assay, AP at dose of $4.46 \mu \mathrm{M}$ indicated the best effect on ALP gene expression. Wnt5a, Fzd2 and Gsk-3b were all significantly down regulated by AP treatment at a dose of $8.92 \mu \mathrm{M}(\mathrm{P}<0.05)$.It is indicated that the down regulated Wnt5a, Fzd2 and Gsk-3b was associated with the up-regulated Wnt4, $\beta$-catenin and osteo-genes.

\section{KARGER}




\section{Cellular Physiology Cell Physiol Biochem 2015;36:2327-2339

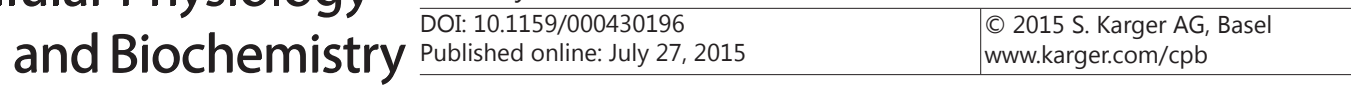

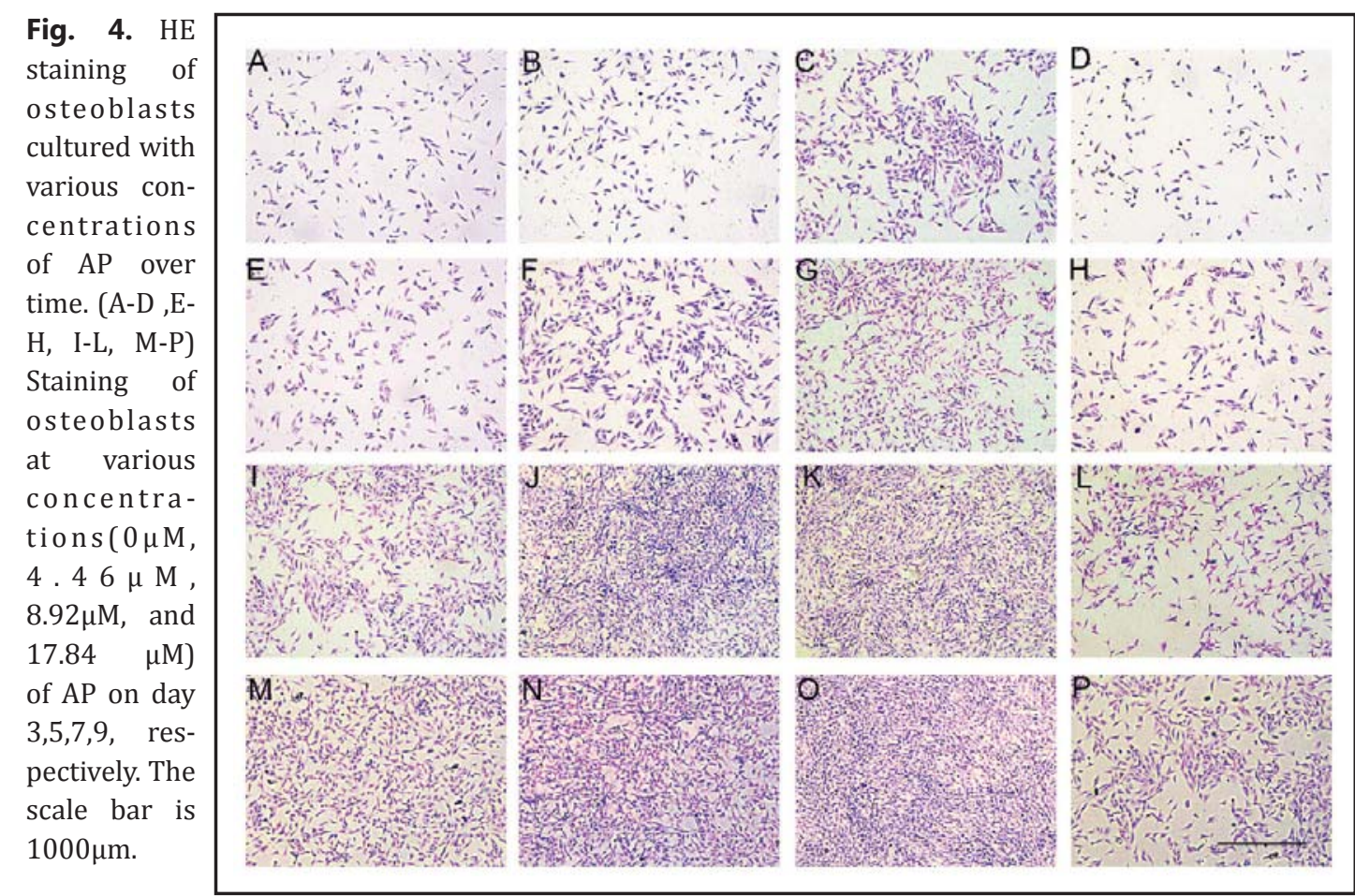

Fig. 5. (A-D , EH, I-L, M-P) OCN staining of osteoblasts at various concentrations $((0 \mu \mathrm{M}, \quad 4.46 \mu \mathrm{M}$, $8.92 \mu \mathrm{M}$, and 17.84 $\mu \mathrm{M})$ of AP on day $3,5,7,9$, respectively. Negative control staining was presented in Fig. $\mathrm{Q}$ the positive rate was showed in Fig.R. The scale bar is $1000 \mu \mathrm{m}$.

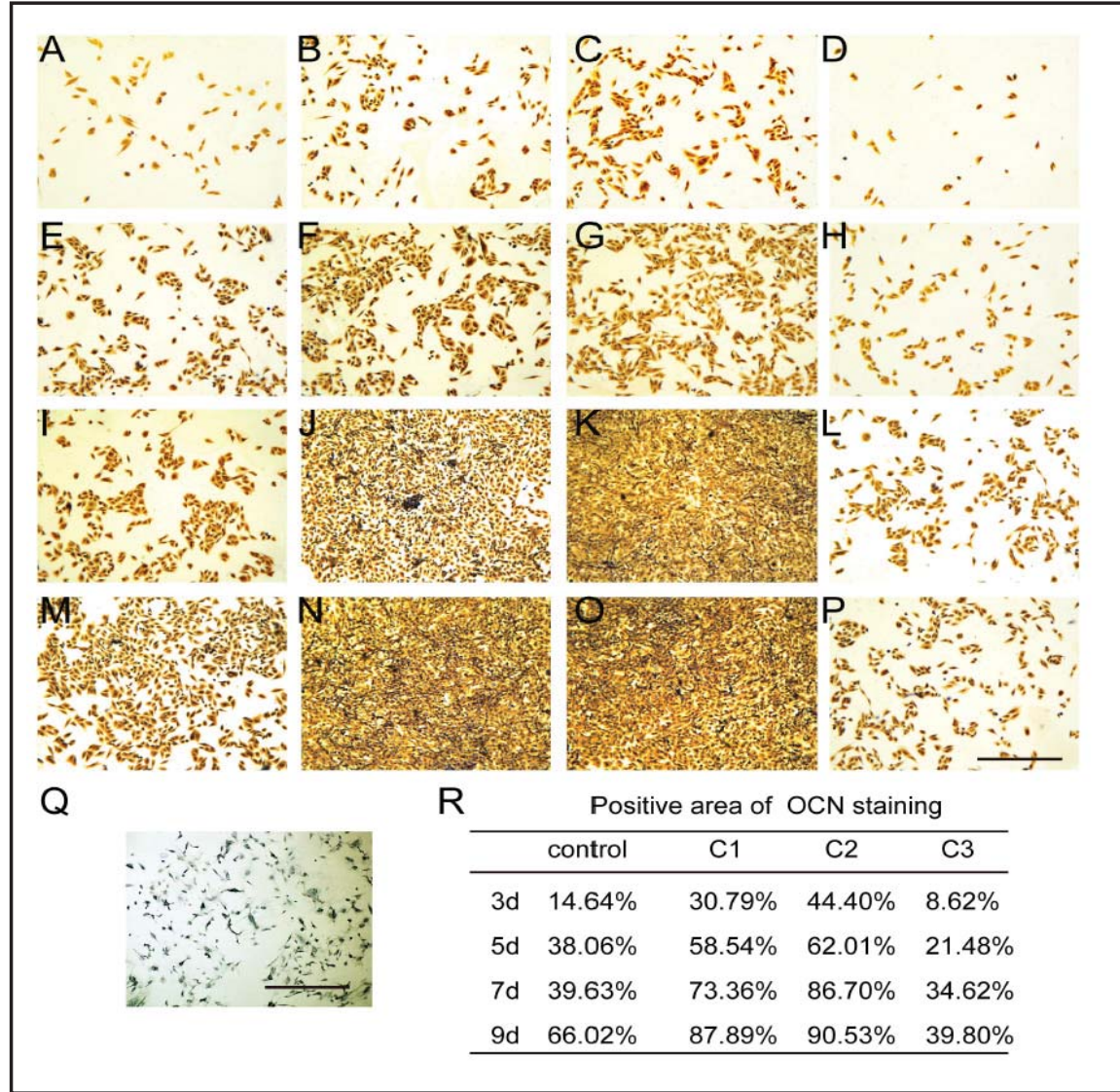

Western blot analysis

Proteins of all groups were collected for Western blotting after 5 days culture (Fig. 6 (B)). The increased expression of total $\beta$-catenin in 4.46 and $8.92 \mu \mathrm{M}$ AP-treated cells, as compared to the control group $(\mathrm{P}<0.01)$. And the active $\beta$-catenin showed the same expression, but 


\section{Cellular Physiology Cell Physiol Biochem 2015;36:2327-2339 \begin{tabular}{l|l|l}
\hline DOI: 10.1159/000430196 & O 2015 S. Karger AG, Basel
\end{tabular} and Biochemistry Published online: July 27, 2015 www.karger.com/cpb

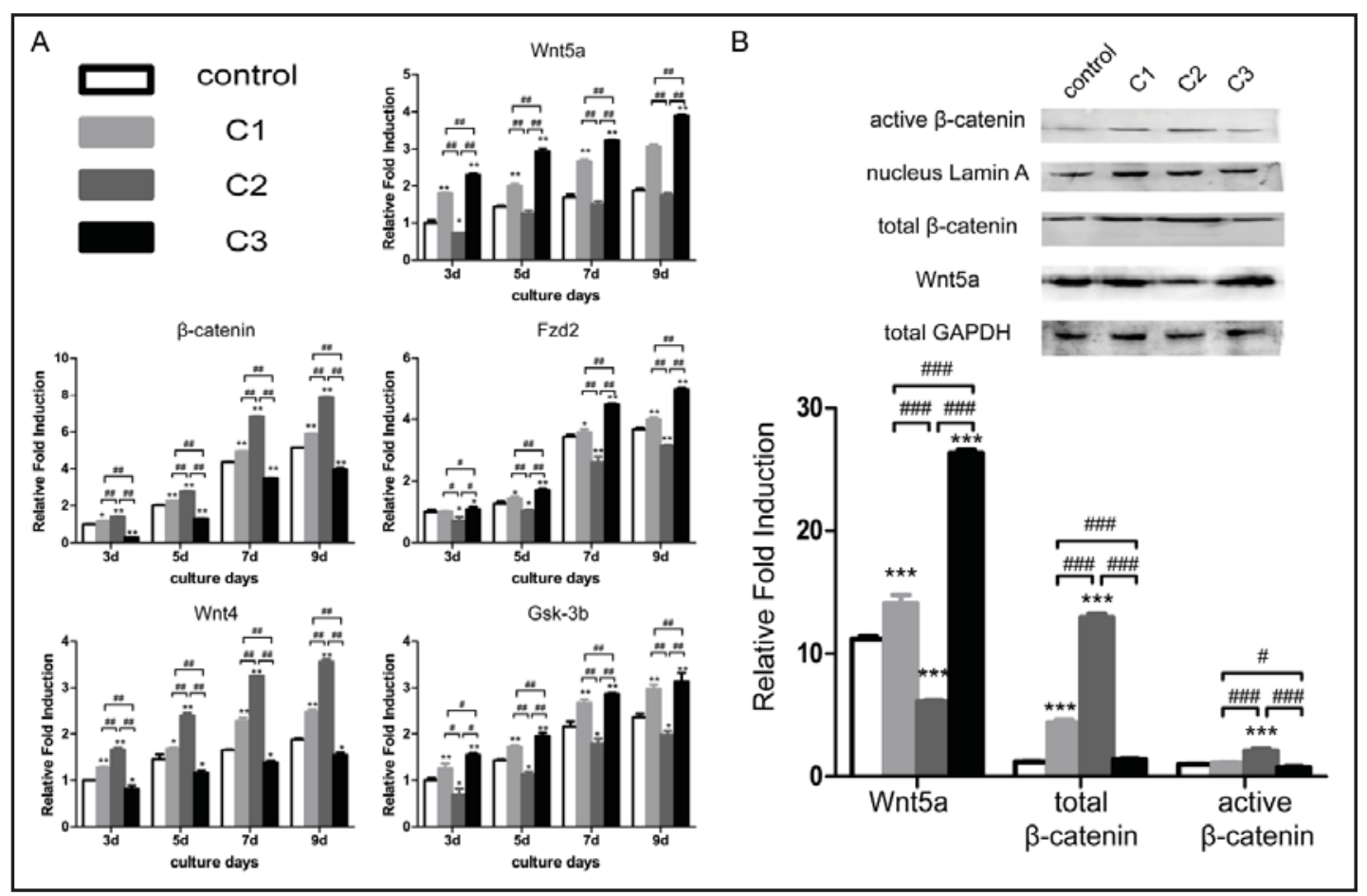

Fig. 6. (A) Quantitative real-time PCR was used to analyze the progression of the expression of WNT/ $\beta$ catenin signaling pathway genes $\beta$-catenin , Wnt4, Wnt5a , Fzd2 , Gsk-3b in osteoblasts cultured in various concentrations of AP for 3, 5, 7 9days. The control group value was set to 1 and values are expressed as means \pm SEM. * , \# indicate $\mathrm{P}<0.05,{ }^{* *}$,\#\# indicate $\mathrm{P}<0.01$ and ${ }^{* * *}$, \#\#\# indicate $\left.\mathrm{P}<0.001\right)$.(B) Western Blot was used to analyze the progression of the expression of WNT/ $\beta$-catenin signaling pathway proteins $\beta$-catenin and Wnt5a in osteoblasts cultured in various concentrations of AP for 5 days. * \# indicate $\mathrm{P}<0.05$, **,\#\# indicate $\mathrm{P}<0.01$ and ${ }^{* * *}$, \#\#\# indicate $\mathrm{P}<0.001$ ).

Fig. 7. Schematic description of WNT signaling pathway activated by AP.AP promotes the expression of WNT4, which inhibit Wnt5a binding with Fzd2.The combination of Wnt5a and Fzd2 could upregulating the expression of Gsk3b, which suppress $\beta$-catenin expression. Runx2 is one of the target gene of $\beta$-catenin, and both BMP-2 and RUNX2 contribute to osteogenic function.

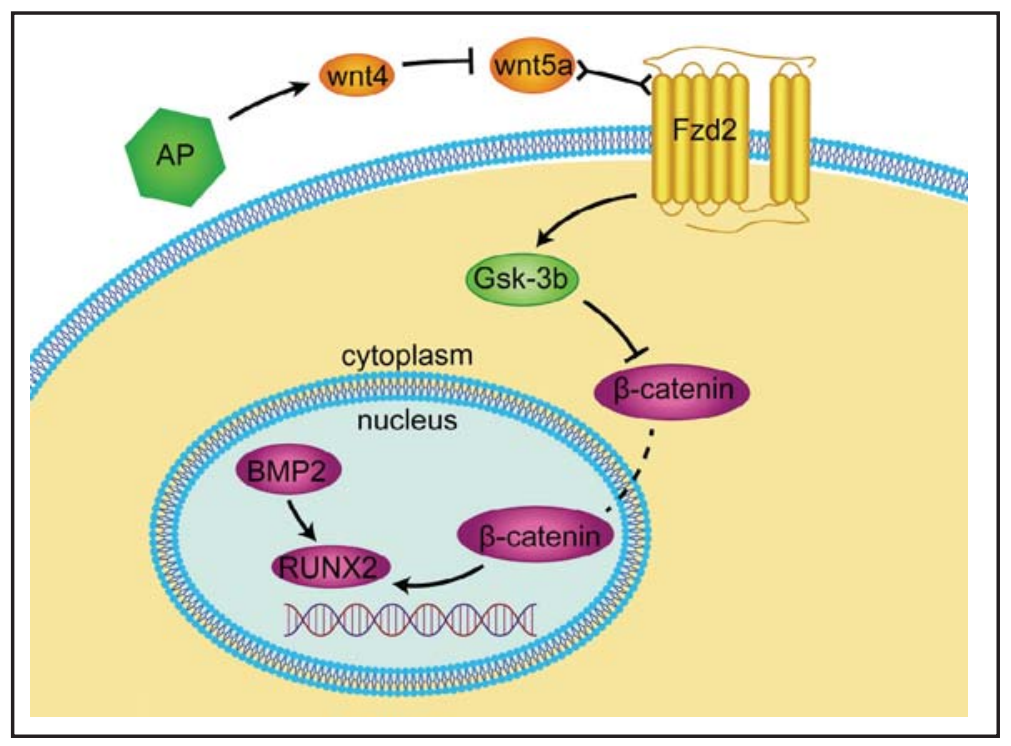

only AP at dose of $8.92 \mu \mathrm{M}$ was significantly up-regulated. Among 3 AP group, the expression of Wnt5a presents the opposite trend to $\beta$-catenin. Although not all the statistics among all group was significantly different, the expression of Wnt5a and active/total $\beta$-catenin was consistent to the PCR result. 


\section{Cellular Physiology Cell Physiol Biochem 2015;36:2327-2339 \\ \begin{tabular}{l|l} 
DOI: 10.1159/000430196 & $\begin{array}{l}\text { C } 2015 \text { S. Karger AG, Basel } \\
\text { www.karger.com/cpb }\end{array}$ \\
\hline
\end{tabular}}

\section{Discussion}

Andrographispaniculata (A. paniculata) has a long history of therapy in various diseases without obvious adverse side effects since ancient China. As the main active constituent of A. paniculata, AP was reported to prevent osteoclast-related bone resorption [14]. Besides, AP has the ability to activate the canonical Wnt signalling pathway which is crucial for bone formation and inhibition of osteoporosis. All the findings suggested that AP may be potential agent to treat osteoporosis, which may exert an effect on osteoblastic bone formation.

During the bone formation, the osteoblasts will express numerous markers such as ALP, BSP, OCN and various cytokines. ALP, which is one of the well defined markers of pre-osteoblast differentiation, plays an important role in osteoid formation and bone mineralization, just as a catalyst in the process of bone formation [26]. Our results showed that AP could significantly increase the level of ALP, indicating that AP can promote the preosteoblast maturation which is essential for mineralization. As a consequence of continuously increased ALP heralding the differentiation stage, BSP and OCN which were specific markers in mineralized tissues [27-29] were also up-regulated by AP. The results indicated that AP has potent regulative effects on osteoblasts maturation.

Runx2 is a noncollagenous, highly conserved transcription factor involved in the regulation of mineralized matrix of bone. Mutations in the Runx2 gene in mouse and human lead to cleidocranial dysplasia and critical defects in bone formation [30,31] In our study, upregulated expression of Runx2 was observed by rt-PCR in osteoblasts treated with AP at dose of $4.46 \mu \mathrm{M}$ and $8.92 \mu \mathrm{M}$ as compared to control (Fig. 2). It has been reported that Runx2 binds to the osteoblast specific cis acting element which is found in the promoter region of all major osteoblast specific genes like OCN, BSP, ALP and control their expression [32]. Hence, it is reasonable to deduce that AP may regulate the osteogenic related gene expression through the modulation of Runx2 in osteoblastic cells.

To specifically know the molecular target of AP, we next characterized the cellular signaling events that may be activated by AP. Given the importance of the canonical Wnt signalling pathway which can be activated by AP [24], Wnt/ $\beta$-catenin signaling related genes were identified. Our study showed that the expression of $\beta$-catenin, Wnt 4 mRNA was significantly up-regulated, and GSK3b, WNT5a, Fzd2 downregulated by AP, suggesting that AP could affect the osteoblasts metabolism by activating the Wnt/ $\beta$-catenin signaling pathway. Wnt 4 and $\beta$-catenin plays important role in osteogenesis and bone formation, which prevents skeletal aging and bone loss in vivo [22]. Increased expression of Wnt 4 and $\beta$-catenin after treatment of AP reveals the proosteogenic effect of AP. On the other hand, inhibition of other wnt-related genes like GSK3b, Wnt5a, Fzd2 by AP indicates the potential of AP on prevention of bone loss. In the process of osteogensis, Wnt5a antagonizes Wnt/ $\beta$-catenin signaling through the Wnt/Calcium pathway [33] and $\beta$ - catenin degradation by promoting GSK3b [34]. Studies have shown that haploinsufficiency of GSK-3b can partially rescue dwarfism caused by cGMP-dependent protein kinase II deficiency [35]. In the $\beta$-catenin -independent pathway, Wnt5a activated Rac by the acquirement of Frizzled2 (Fzd2) through a clathrinmediated route in response [36]. Thus, suppression of GSK3b, Wnt5a, Fzd2 to some extent may contribute to osteogenesis.

At the molecular level shown in Fig. 7, the AP-activated Wnt signalling pathway may be partially associated with increased abundance of the transcription factors $\beta$-catenin and BMP2, all crucial for skeletal growth and development. Runx2 is also a direct target of the canonical WNT signaling pathway [37], which is upregulated by $\beta$-catenin that accumulates in the nucleus and binds LEF-1/TCF to promote differentiation and proliferation of osteoblasts [38]. BMP2, signaling component distincted from the known Wnt/ $\beta$-catenin signal, may stimulate processes that cooperate with activated $\beta$-catenin to promote osteoblast differentiation $[39,40]$. Vascular calcification in chronic kidney disease is induced by BMP2 via $\mathrm{Wnt} / \beta$-catenin pathway [41].

Osteoblasts cultured in vitro, which have similar biological characteristics of osteoblasts in vivo, is the primary means to study the metabolic diseases of skeleton [42]. In the present 


\section{Cellular Physiology Cell Physiol Biochem 2015;36:2327-2339 and Biochemistry \begin{tabular}{l|l}
${ }$ Published online: July 27, $2015 }$ & $\begin{array}{l}\text { C 2015 S. Karger AG, Basel } \\
\text { www.karger.com/cpb }\end{array}$ \\
\hline
\end{tabular} Jiang et al.: Andrographolide Exerts Pro-Osteogenic Effect}

study, AP has an effect on the proliferation of osteoblasts in vitro in a dose-dependent manner, as evidenced by MTT analysis, cell viability assay and histological evaluation. Especially at the concentration of $8.92 \mu \mathrm{M}$, AP could best support cell growth in all the groups. The results suggested the potency of AP as an osteogenic enhancer in vitro may broaden its utility in therapy of osteoporosis in clinic.

In conclusion, our results demonstrate for the first time that AP exerts an effect on osteoblastogenesis by activating wnt/ $\beta$-catenin signaling pathway. These activities may be partially controlled by transcription factors $\beta$-catenin and Runx2, which were upregulated after treatment with AP. The study indicates AP can be used as a pro-osteogenic agent for the therapy of osteoporosis. Nevertheless, we should stay aware that this study presents some limitations, and further studies are required to fully determine the contribution of AP properties in vivo.

\section{Acknowledgments}

This work has been financially supported by Guangxi Scientific Research and Technological Development Foundation (Grant No. Guikehe 14125008-2-14), Guangxi Science Fund for Distinguished Young Scholars (Grant No. 2014GXNSFGA118006). This work has been supported by Research Center for Regenerative Medicine and Collaborative Innovation Center of Guangxi Biological Medicine.

\section{Disclosure Statement}

The authors confirm that this article content has no conflicts of interest.

\section{References}

1 Kaunitz AM, McClung MR, Feldman RG, Wysocki S: Postmenopausal osteoporosis: Fracture risk and prevention. J Fam Pract 2009;58:S1-S6.

2 McClung M, Harris ST, Miller PD, Bauer DC, Davison KS, Dian L, Hanley DA, Kendler DL, Yuen CK, Lewiecki EM: Bisphosphonate therapy for osteoporosis: Benefits, risks, and drug holiday. Am J Med 2013;126:13-20.

3 Pereira JV, Modesto-Filho J, Agra MDF, Barbosa-Filho JM: Plant and plant-derived compounds employed in prevention of the osteoporosis. Acta Farm Bonaerense 2002;21:223-234.

4 Yuh-Chiang Shen C-FC, Wen-Fei Chiou: Andrographolide prevents oxygen radical production by human neutrophils: Possible mechanism(s) involved in its anti-inflammatory effect. Brit J Pharmacol 2002;135:399-406.

5 Niranjan Reddy VL, Malla Reddy S, Ravikanth V, Krishnaiah P, Venkateshwar Goud T, Rao TP, Siva Ram T, Gonnade RG, Bhadbhade M, Venkateswarlu Y: A new bis-andrographolide ether fromandrographis paniculatanees and evaluation of anti-hiv activity. Nat Prod Res 2005;19:223-230.

6 Zhao J, Yang G, Liu H, Wang D, Song X, Chen Y: Determination of andrographolide, deoxyandrographolide and neoandrographolide in the chinese herb andrographis paniculata by micellar electrokinetic capillary chromatography. 2002;13:222-227.

7 Sareer 0, Ahmad S, Umar S: Andrographis paniculata: A critical appraisal of extraction, isolation and quantification of andrographolide and other active constituents. Nat Prod Res 2014;28:2081-2101.

8 Abu-Ghefreh AA, Canatan H, Ezeamuzie CI: In vitro and in vivo anti-inflammatory effects of andrographolide. Int Immunopharmacol 2009;9:313-318.

9 Bao Z, Guan S, Cheng C, Wu S, Wong SH, Kemeny DM, Leung BP, Wong WSF: A novel antiinflammatory role for andrographolide in asthma via inhibition of the nuclear factor-кb pathway. Am J Resp Crit Care 2009;179:657-665.

10 Chen JH, Hsiao G, Lee AR, Wu CC, Yen MH: Andrographolide suppresses endothelial cell apoptosis via activation of phosphatidyl inositol-3-kinase/akt pathway. Biochem Pharmacol 2004;67:1337-1345. 


\section{Cellular Physiology Cell Physiol Biochem 2015;36:2327-2339 \begin{tabular}{ll|l} 
and Biochemistry & $\begin{array}{l}\text { DOI: 10.1159/000430196 } \\
\text { Published online: July 27, 2015 }\end{array}$ & $\begin{array}{l}\text { ○ 2015 S. Karger AG, Basel } \\
\text { www.karger.com/cpb }\end{array}$ \\
\hline
\end{tabular}}

11 Hidalgo MA, Romero A, Figueroa J, Cortes P, Concha, II, Hancke JL, Burgos RA: Andrographolide interferes with binding of nuclear factor-kappab to DNA in hl-60-derived neutrophilic cells. Br J Pharmacol 2005;144:680-686.

12 Negi AS, Kumar JK, Luqman S, Shanker K, Gupta MM, Khanuja SP: Recent advances in plant hepatoprotectives: A chemical and biological profile of some important leads. Med Res Rev 2008;28:746772.

13 Wang YJ, Wang JT, Fan QX, Geng JG: Andrographolide inhibits nf-kappabeta activation and attenuates neointimal hyperplasia in arterial restenosis. Cell Res 2007;17:933-941.

14 Zhai ZJ, Li HW, Liu GW, Qu XH, Tian B, Yan W, Lin Z, Tang TT, Qin A, Dai KR: Andrographolide suppresses rankl-induced osteoclastogenesis in vitro and prevents inflammatory bone loss in vivo. Br J Pharmacol 2014;171:663-675.

15 Zhai Z, Qu X, Yan W, Li H, Liu G, Liu X, Tang T, Qin A, Dai K: Andrographolide prevents human breast cancerinduced osteoclastic bone loss via attenuated rankl signaling. Breast Cancer Res Treat 2014;144:33-45.

16 Al Batran R, Al-Bayaty FH, Al-Obaidi MM: In-vivo effect of andrographolide on alveolar bone resorption induced by porphyromonas gingivalis and its relation with antioxidant enzymes. Biomed Res Int 2013;2013:276329.

17 Baron R, Kneissel M: Wnt signaling in bone homeostasis and disease: From human mutations to treatments. Nat Med 2013;19:179-192.

18 Fei Y, Hurley MM: Role of fibroblast growth factor 2 and wnt signaling in anabolic effects of parathyroid hormone on bone formation. J Cell Physiol 2012;227:3539-3545.

19 Brunetti G, Faienza MF, Piacente L, Ventura A, Oranger A, Carbone C, Benedetto AD, Colaianni G, Gigante M, Mori G, Gesualdo L, Colucci S, Cavallo L, Grano M: High dickkopf-1 levels in sera and leukocytes from children with 21-hydroxylase deficiency on chronic glucocorticoid treatment. Am J Physiol Endocrinol Metab 2013;304:E546-554.

20 Kim W, Kim M, Jho EH: Wnt/beta-catenin signalling: From plasma membrane to nucleus. Biochem J 2013;450:9-21.

21 Xu XJ, Shen L, Yang YP, Zhu R, Shuai B, Li CG, Wu MX: Serum beta -catenin levels associated with the ratio of rankl/opg in patients with postmenopausal osteoporosis. Int J Endocrinol 2013;2013:534352.

22 Yu B, Chang J, Liu Y, Li J, Kevork K, Al-Hezaimi K, Graves DT, Park NH, Wang CY: Wnt4 signaling prevents skeletal aging and inflammation by inhibiting nuclear factor-kappab. Nat Med 2014;20:1009-1017.

23 Chen Y, Chen L, Yin Q, Gao H, Dong P, Zhang X, Kang J: Reciprocal interferences of tnf-alpha and wnt1/ beta-catenin signaling axes shift bone marrow-derived stem cells towards osteoblast lineage after ethanol exposure. Cell Physiol Biochem 2013;32:755-765.

24 Tapia-Rojas C, Schuller A, Lindsay CB, Ureta RC, Mejias-Reyes C, Hancke J, Melo F, Inestrosa NC: Andrographolide activates the canonical wnt signalling pathway by a mechanism that implicates the nonatp competitive inhibition of gsk-3beta: Auto regulation of gsk-3beta in vivo. Biochem J 2015;466:415430 .

25 Orriss IR TS, Arnett TR: Rat osteoblast cultures. Methods Mol Biol 2012;816:31-41.

26 Xia B, Xu B, Sun Y, Xiao L, Pan J, Jin H, Tong P: The effects of liuwei dihuang on canonical wnt/beta-catenin signaling pathway in osteoporosis. J Ethnopharmacol 2014;153:133-141.

27 Hakki SS, Bozkurt SB, Hakki EE, Belli S: Effects of mineral trioxide aggregate on cell survival, gene expression associated with mineralized tissues, and biomineralization of cementoblasts. J Endod 2009;35:513-519.

28 D'Errico JA, MacNeil RL, Takata T, Berry J, Strayhorn C, Somerman MJ: Expression of bone associated markers by tooth root lining cells, in situ and in vitro. Bone 1997;20:117-126.

29 Hakki SS, Wang D, Franceschi RT, Somerman MJ: Bone sialoprotein gene transfer to periodontal ligament cells may not be sufficient to promote mineralization in vitro or in vivo. J Periodontol 2006;77:167-173.

30 Florian Otto HK, and Stefan Mundlos: Mutations in the runx2 gene in patients with cleidocranial dysplasia. Hum Mutat 2002;19:209-216.

31 Yoshida T, Kanegane H, Osato M, Yanagida M, Miyawaki T, Ito Y, Shigesada K: Functional analysis of runx2 mutations in cleidocranial dysplasia: Novel insights into genotype-phenotype correlations. Blood Cells Mol Dis 2003;30:184-193.

32 Ducy P, Starbuck M, Priemel M, Shen J, Pinero G, Geoffroy V, Amling M, Karsenty G: A cbfa1-dependent genetic pathway controls bone formation beyond embryonic development. Genes Dev 1999;13:1025-1036. 


\section{Cellular Physiology Cell Physiol Biochem 2015;36:2327-2339 \begin{tabular}{l|l} 
DOI: 10.1159/000430196 & O 2015 S. Karger AG, Basel
\end{tabular} and Biochemistry Published online: July 27, 2015 www.karger.com/cpb}

Jiang et al.: Andrographolide Exerts Pro-Osteogenic Effect

33 Ishitani T, Kishida S, Hyodo-Miura J, Ueno N, Yasuda J, Waterman M, Shibuya H, Moon RT, Ninomiya-Tsuji J, Matsumoto K: The tak1-nlk mitogen-activated protein kinase cascade functions in the wnt-5a/ca2+ pathway to antagonize wnt/ -catenin signaling. Mol Cell Biol 2003;23:131-139.

34 Topol L, Jiang X, Choi H, Garrett-Beal L, Carolan PJ, Yang Y: Wnt-5a inhibits the canonical wnt pathway by promoting gsk-3-independent beta-catenin degradation. J Cell Biol 2003;162:899-908.

35 Kawasaki Y, Kugimiya F, Chikuda H, Kamekura S, Ikeda T, Kawamura N, Saito T, Shinoda Y, Higashikawa A, Yano F, Ogasawara T, Ogata N, Hoshi K, Hofmann F, Woodgett JR, Nakamura K, Chung UI, Kawaguchi H: Phosphorylation of gsk-3beta by cgmp-dependent protein kinase ii promotes hypertrophic differentiation of murine chondrocytes. J Clin Invest 2008;118:2506-2515.

36 Sato A, Yamamoto H, Sakane H, Koyama H, Kikuchi A: Wnt5a regulates distinct signalling pathways by binding to frizzled2. Embo J 2010;29:41-54.

37 Gaur T, Lengner CJ, Hovhannisyan H, Bhat RA, Bodine PV, Komm BS, Javed A, van Wijnen AJ, Stein JL, Stein GS, Lian JB: Canonical wnt signaling promotes osteogenesis by directly stimulating runx2 gene expression. J Biol Chem 2005;280:33132-33140.

38 Nusse R: Wnt signaling in disease and in development. Cell Res 2005;15:28-32.

39 Bain G, Muller T, Wang X, Papkoff J: Activated $\beta$-catenin induces osteoblast differentiation of c3h10t1/2 cells and participates in bmp2 mediated signal transduction. Biochem Biophys Res Commun 2003;301:8491.

40 Rawadi G, Vayssiere B, Dunn F, Baron R, Roman-Roman S: Bmp-2 controls alkaline phosphatase expression and osteoblast mineralization by a wnt autocrine loop. J Bone Miner Res 2003;18:1842-1853.

41 Rong S, Zhao X, Jin X, Zhang Z, Chen L, Zhu Y, Yuan W: Vascular calcification in chronic kidney disease is induced by bone morphogenetic protein-2 via a mechanism involving the wnt/beta-catenin pathway. Cell Physiol Biochem 2014;34:2049-2060.

42 Czekanska EM, Stoddart MJ, Richards RG, Hayes JS: In search of an osteoblast cell model for in vitro research. Eur Cell Mater 2012;24:1-17. 